\title{
ANAESTHETIC PROBLEMS ASSOCIATED WITH THE TREATMENT OF CARDIOVASCULAR DISEASE: II. BETA-ADRENERGIC ANTAGONISTS
}

\author{
D.C. Chung
}

\begin{abstract}
There are a number of beta-adrenergic antagonists available for general clinical use. The pharmacological action of these agents in patients with ischaemic heart disease and hypertensive cardiovascular disease is similar to that of the prototype, propranolol.

No less than three per cent of patients treated with propranolol develop life-threatening cardiac complications. Since the combined circulatory depressant effect of beta blockade and anaesthesia is a cause for concern, surgical patients, who are also treated with beta antagonists for their cardiovascular disease, should be properly assessed and prepared. Due to individual differences in receptor sensitivity, pharmacokinetic factors and compliance with treatment, the daily maintenance dose does not reflect the degree of beta blockade. A thorough examination of the cardiovascular system is helpful. There is no reason to withhold or reduce the maintenance dose before surgery in the optimally treated patient; but corrective measures are necessary in the patient on a toxic dose.

Choice of anaesthetic agents should be made according to known interactions between these agents and beta-adrenergic antagonists. The combined circulatory depressant effect of halothane as well as morphine and beta blockade is additive, while that of enflurane and beta blockade is less predictable. There is minimal interaction between isoflurane and propranolol, but the combination of methoxyflurane and practolol seems to be unacceptable. There are both practical and theoretical disadvantages to the use of succinylcholine because of its muscarinic action and the use of d-tubocurarine because of its ganglionic blocking effect. On the other hand, no objection to the use of dimethyl-tubocurarine and pancuronium exists. To avoid adverse interaction, neostigmine should be given in small increments, and only after the administration of atropine.

Since acute myocardial infarction can strike as early as twenty-four hours after abrupt withdrawal, the surgical patient treated with beta antagonists should be allowed to go back to his maintenance dose as early as possible after operation. For patients who have to abstain from oral intake postoperatively, intravenous infusion of propranolol is recommended.

If life-threatening bradycardia and hypotension should develop, the use of beta agonists can overcome the competitive beta-adrenergic blockade. Atropine, aminophylline, cardiac glycosides, calcium salts and glucagon can also be used to counteract the circulatory effects of beta antagonists.
\end{abstract}

Key Words: AnAesthesia, cardiovascular disease; Heart, Beta-adrenergic antagonists.

Propranolol (INDERAL) is the first effective and safe beta-adrenergic antagonist to gain wide acceptance. ${ }^{1}$ Since its introduction in 1964 , contradictory opinions have been expressed on the anaesthetic management of patients on chronic therapy. Some authors have recommended the

D.C. Chung, M.D., F.R.C.P.(C), Assistant Professor, Department of Anaesthesia, University of Western Ontario, University Hospital, London, Ontario, Canada.

This paper will form a chapter of a book to be published by Edward Arnold Publishers Ltd., London, England, in 1982 under the title "General Anaesthesia In Patients With Ischaemic Heart Disease", to be distributed in Canada by Gage Educational Publishers Ltd. Copyright reserved by the author. withdrawal of this agent for twenty-four hours to two weeks before elective surgery; $;^{2.3}$ others have shown that it was safe to anaesthetize patients on chronic therapy even when it was given six hours before cardiac $^{4,5}$ or other surgery. ${ }^{6.7}$ Betaadrenergic antagonists are potent myocardial depressants. It has been estimated that not less than nine per cent of in-patients on propranolol had adverse reactions and nearly a third of these were life-threatening cardiac complications. ${ }^{8}$ It is likely that the real difference in the experience of these authors lies not in substance but in the method of selection and preparation of their patients. With better understanding of the pharmacology of the beta-adrenergic system and its 


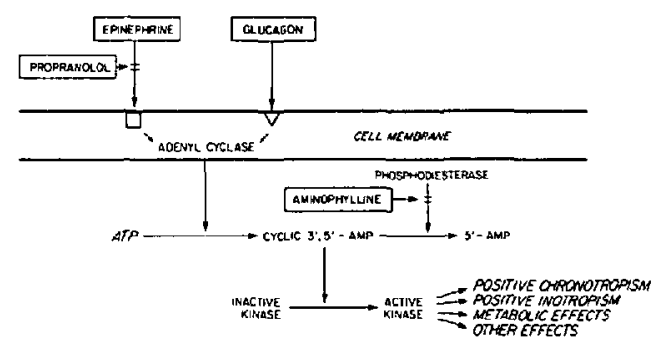

FIGURE 1 The beta-adrenergic and the glucagonergic mechanism mediated by cyclic 3', 5' - AMP. Propranolol can block the action of beta agonists at beta receptor sites while aminophylline can exert beta-like effects by inhibiting the breakdown of cyclic AMP. (Please refer to the text for details).

blockade and of the interaction of beta antagonists with anaesthetic agents, it is appropriate to look afresh at this controversial topic.

Besides propranolol there are now a number of other beta-adrenergic antagonists available. They include metoprolol (Betaloc and Lopresor), nadolol (Corgard), pindolol (Visken), and timolol (Blocadren). Cardio-selectivity is claimed for some of these, intrinsic agonist activity for others. However, the pharmacology of beta blockade by these agents in patients with cardiovascular disease is similar. ${ }^{9.10}$ Propranolol is still by far the most popular member of the family and is the only agent that can be given intravenously. Therefore, the patient on propranolol will be discussed as a prototype in this review.

\section{The Beta-adrenergic Mechanism AND ITS BLOCKADE}

Epinephrine, the naturally occurring beta agonist, is a messenger molecule capable of combining with specific receptor sites on the myocardial cell membrane surface (Figure 1). Such an interaction will result in the activation of the enzyme adenyl cyclase which catalyses the conversion of ATP to cyclic AMP. Cyclic AMP in turn catalyses the conversion of inactive kinase to active kinase. Cellular mechanisms are altered by active kinase leading to the chronotropic and inotropic effects of epinephrine. ${ }^{\lfloor-13}$

Propranolol is an epinephrine analogue capable of combining with beta-adrenergic receptors without activating adenyl cyclase. It is a competitive antagonist ${ }^{14}$ similar to the action of $\mathrm{cu}$ rare at the myoneural junction. This blockade can be overcome by increasing the concentration of the agonist.
The cyclic AMP-kinase mediated chronotropic and inotropic effects can be activated by agents other than beta-adrenergic agonists. Glucagon, when combined with specific surface receptors, will also activate adenyl cyclase and lead to the conversion of ATP to cyclic AMP and the conversion of inactive kinase to active kinase ${ }^{11}$ (Figure 1). Aminophylline, by inhibiting phospho-diesterase, will retard the enzymatic breakdown of cyclic AMP and will increase the effect of beta-adrenergic agents ${ }^{15}$ (Figure 1).

\section{The Clinical Pharmacology of PROPRANOLOL}

Since the introduction of propranolol, the indications for beta blockade have grown to include ischaemic heart disease, obstructive cardiomyopathy, supraventricular and ventricular arrhythmias, essential hypertension, phaeochromocytoma, thyrotoxicosis, certain tremors and psychiatric disorders and glaucoma. The majority of patients treated with beta antagonists are those with ischaemic heart disease and hypertensive cardiovascular disease.

Propranolol alleviates symptoms and signs of myocardial ischaemia and improves the exercise tolerance of patients with ischaemic heart disease. As a result of beta-adrenergic blockade, heart rate, cardiac output, myocardial contractility, ventricular systolic pressure and its rate of rise are reduced. Consequently myocardial oxygen demand falls. On the contrary, ventricular volume and ejection time are increased and myocardial oxygen requirement rises. The sum total of all these effects is a net reduction in myocardial oxygen consumption which is beneficial to the patient with myocardial ischaemia. ${ }^{14}$ By virtue of its activity as a beta antagonist on the excitable and conducting tissues of the heart and its quinidine-likc activity on myocardial cell membrane, propranolol is found useful in the treatment of arrhythmias. ${ }^{16.17}$

Propranolol is a potent inhibitor of renin secretion by the kidneys. Its anti-hypertensive action is most effective in patients with high or normal plasma renin activity. ${ }^{18.19}$ Since inhibition of renin secretion will reduce aldosterone secretion, propranolol will prevent the compensatory salt and water retention accompanying vasodilator therapy. Therefore, propranolol is often combined with a diuretic ${ }^{19}$ or a vasodilator ${ }^{20}$ in the control of hypertension. Other anti-hypertensive actions of propranolol include a de- 
crease in cardiac output ${ }^{21.22}$ and cerebral effect $^{23.24}$ in high doses.

\section{Absorption and Fate}

Propranolol is completely absorbed from the gastro-intestinal tract ${ }^{25}$ and is eliminated almost entirely by metabolism ${ }^{26}$ in the liver. Hepatic extraction during its transfer from the gut to the systemic circulation (pre-systemic or "first pass" hepatic elimination) is high. ${ }^{27}$ The outcome is a low bio-availability. When absorbed, 90 to $95 \mathrm{per}$ cent is bound to plasma protein. ${ }^{28}$ After oral but not after intravenous administration, an equipotent active metabolite, 4-hydroxypropranolol, ${ }^{29}$ with a shorter half-life, can be detected. However, at the end of a six-hourly dose interval after oral administration, the effect of this metabolite can be ignored.

A plasma level of 50 to $100 \mu \mathrm{g} / \mathrm{ml}$ at the end of a six-hourly oral dose interval is therapeutic and will confer a high degree of beta blockade. ${ }^{30}$ The oral dose required by patients varies widely. Several factors are responsible: ${ }^{31}$

(1) There may be a seven- to twenty-fold difference in plasma level of propranolol among different individuals after the same oral dose. ${ }^{30.32}$ This large variation is the result of different rates of pre-systemic hepatic extraction.

(2) Only the unbound fraction is free to combine with receptor molecules. The difference in protein binding of 90 to 95 per cent ${ }^{28}$ may seem small, but it means a two-fold difference in the availability of the active unbound fraction.

(3) There may be a genuine difference in receptor sensitivity between different individuals. ${ }^{33}$

(4) The underlying mechanism of action may be different. For example, hypertensive patients with high or normal plasma renin activity require only a modest dose of propranolol. In some other patients, doses up to $2000 \mathrm{mg}$ are necessary..$^{34}$ The anti-hypertensive action of propranolol in this second group of patients is probably through its central nervous system effect ${ }^{23,24}$ rather than the lowering of plasma renin activity.

(5) Propranolol is a competitive antagonist. Its effect depends, to a large extent, on the underlying sympathetic tone which differs from patient to patient and may vary with the daily activities of the patient. ${ }^{35}$

(6) Poor compliance of some patients is also a factor to be considered. ${ }^{31}$ They may not be taking the prescribed dose regularly.

With intravenous administration, pre-systemic hepatic elimination does not occur and only a fraction of the oral dose is necessary to produce a similar degree of beta blockade. No active metabolites are detectable after intravenous administration.

Both bound and unbound fractions of propranolol are extracted and metabolized by the liver. ${ }^{36}$ The plasma half-life is three to six hours after oral administration and two to three hours after intravenous administration. ${ }^{35}$ It has been demonstrated that it takes only 24 hours for the complete elimination of propranolol and its metabolites from the myocardium ${ }^{37}$ and that there is no detectable cardiac beta-adrenergic blockade by propranolol or its metabolites as early as 18 hours, and certainly no longer than 48 hours after withdrawal from chronic therapy. ${ }^{38.39}$ However, as the rate of hepatic extraction of propranolol is very sensitive to hepatic blood flow, beta blockade itself, by decreasing cardiac output and hepatic blood flow, ${ }^{40.41}$ will reduce and delay the elimination of propranolol. ${ }^{41.42}$ Similarly, the action of propranolol is prolonged in patients with uncompensated congestive heart failure, in whom it is also contraindicated.

\section{Contraindications and Adverse Reactions}

The contraindications and adverse reactions to propranolol are similar. ${ }^{8}$ It is contraindicated in patients who have bronchospasm, congestive heart failure, hypotension, bradycardia and heart blocks. Its administration should be discontinued should any of these develop during therapy. Propranolol is administered in small increments until a maintenance dose is established. Adverse reactions usually occur early in the course of therapy and are not related to the magnitude of the maintenance dose. Once the maintenance dose is reached, life-threatening complications are unlikely unless there is a change in the underlying pathology.

\section{ANAESTHETIC CONSIDERATIONS}

\section{Preoperative Assessment and Preparation of the Patient}

During the preoperative assessment of patients on propranolol, their medical history and cardiac disability should be reviewed. The combined circulatory depressant effect of beta blockade and anaesthesia is a constant threat to these patients. Profound bradycardia and hypotension is more likely to occur in patients on a toxic dose of the agents. Therefore an effort should be made to 
determine the adequacy of treatment and the possibility of toxicity. Unfortunately, the daily maintenance dose varies from individual to individual because of differences in receptor sensitivity, pharmacokinetic factors and compliance with treatment and is not a reliable guide to the degree of beta blockade. A thorough examination of the cardiovascular system is helpful.

\section{The Optimally Treated Patient}

The usual oral maintenance dose varies between 80 to $320 \mathrm{mg} /$ day. $^{35}$ The patient on an optimum dose of propranolol has a good exercise tolerance, his blood pressure is well controlled and he has no anginal symptoms, congestive heart failure, orthostatic hypotension or electrocardiographic evidence of heart block. The resting heart rate is around $60 / \mathrm{min}$ and will increase by ten per cent or more after routine activities. However, profound bradycardia and hypotension can still occur in the optimally treated patient under the additional depressant effects of anaesthesia, although this is rare.

For such a patient there is little reason for withholding or even reducing the maintenance dose before non-cardiac operations. If operation is scheduled in the morning, the usual evening dose should be allowed the night before; if operation is scheduled late in the day, the morning dose should be given on the day of operation. Atropine should be omitted from the premedication, but should be available in the operating room.

\section{The Patient With Propranolol Toxicity}

Clinical features of propranolol toxicity include symptomatic and inappropriate bradycardia, orthostatic hypotension, reduced exercise tolerance, congestive heart failure and evidence of impaired $A-V$ conduction on the electrocardiogram. The frankly toxic patient is usually obvious and is treated. It is the mildly toxic patient who has escaped attention who is likely to cause concern. Unless propranolol is withdrawn or the dose reduced or supplementary measures taken, life-threatening cardiac complications are likely in such a patient during operation.

In preparing the toxic patient for surgery, withdrawal of propranolol should be gradual because abrupt cessation can be associated with acute coronary insufficiency in some patients. ${ }^{43.44}$ The underlying mechanism of this withdrawal rebound phenomenon is multifactorial.45 Receptor hypersensitivity to catecholamine plays a significant role. This hypersensitive period lasts up to two weeks after withdrawal. ${ }^{46}$ During withdrawal, the patient should be closely observed in hospital and care must be taken in the use of exogenous catecholamine. The return of anginal symptoms, arrhythmias or uncontrolled hypertension are indications for re-institution of propranolol therapy to the last symptom-free dose.

If gradual withdrawal is not possible because operation is urgent, supportive treatment is necessary. Digitalization is indicated for congestive heart failure; implantation of a temporary artificial pacemaker is indicated for bradycardia or heart block. The management of bradycardia and hypotension is discussed in a later section.

\section{The Inadequately Treated Patient}

Some patients would benefit from the introduction of propranolol therapy or from an increase in the dose. These include patients with angina and a high resting heart rate, patients with atrial fibrillation or atrial flutter and a fast ventricular rate not controlled by digitalis, patients with significant ventricular premature beats and hypertensive patients with high or normal plasma renin activity. If time permits, the oral route is preferred; in an emergency, intravenous propranolol is necessary.

Intravenous propranolol should be given slowly, ${ }^{35}$ the first milligram being given over 10 to 15 minutes in increments of 0.1 to $0.2 \mathrm{mg}$ each. During this period, the patient should be observed closely for serious side effects. If no adverse reactions occur after $1 \mathrm{mg}$, it is unlikely that they will occur and the dose can be increased when necessary at a rate of $1 \mathrm{mg}$ every five minutes to a total of $0.1 \mathrm{mg} \cdot \mathrm{kg}^{-1}$.

\section{Management During Operation}

Basic monitoring should include blood pressure, heart rate and electrocardiography. Invasive haemodynamic monitoring should be instituted when indicated. During anaesthesia, the decision to control ventilation or not should rest with the surgical requirement and the cardiorespiratory status of the patient. The combined effect of anaesthetic agents and beta blockade on the circulatory function is predictable, and the choice of agents should be made accordingly.

\section{Succinylcholine}

Succinylcholine is a cholinergic agent. An increase in heart rate is the usual response in adults to a first dose of succinylcholine sufficient for tracheal intubation, ${ }^{47-49}$ even when they are on 
propranolol. ${ }^{50}$ Cardiac slowing can occur following subsequent doses. ${ }^{47-49}$ As its muscarinic effect on the beta-blocked heart is a cause for concern, it is best reserved for situations when it is absolutely indicated. Atropine should be available immediately.

\section{The Curares}

Hypotension following d-tubocurarine can be alarming, particularly when halothane is being used. ${ }^{51,52}$ The administration of d-tubocurarine is best avoided in patients on propranolol. Theoretically its ganglionic blocking effect may make the sympathetic blockade produced on the heart by beta antagonists pharmacologically complicated. Dimethyl-tubocurarine, on the other hand, has no ganglionic blocking activity ${ }^{53}$ and is associated with a lower incidence of hypotension. It is a good choice when it is available. ${ }^{54}$

\section{Pancuronium}

Pancuronium is known for its pressor effects. ${ }^{55}$ It is also a satisfactory agent for tracheal intubation. The increase in heart rate and blood pressure can be minimized by a slow rate of administration and it is unlikely to vitiate the beneficial effect of propranolol.

\section{Narcotic Analgesics}

There has been no clinical report of specific adverse interaction between narcotic analgesics and propranolol to date. The myocardial effect of morphine alone is insignificant in man. Hypotension following the administration of morphine is mediated by dilatation of arterial resistance and venous capacitance vessels. ${ }^{56}$ In dogs, it has been found that the circulatory effect of morphine and propranolol was simply additive. ${ }^{57}$

\section{Inhalational Agents}

There is always some concern about the combined circulatory depressant effect of inhalational anaesthetics and propranolol. Of the two major agents, enflurane is a more potent circulatory depressant than halothane. ${ }^{58}$ In dogs, the depressant effect of halothane and propranolol is simply additive, ${ }^{57.59}$ while the combination of enflurane and propranolol is less compatible. ${ }^{60}$ For these reasons, halothane is deemed a safer agent in these patients. Similar studies indicate that the newer agent, isoflurane, is better tolerated than halothane in the presence of moderate to profound beta-adrenergic blockade by propranolol;61 but it seems that the combined depres- sant effect of methoxyflurane and practolol is unacceptable. ${ }^{62}$

\section{Neostigmine}

The muscarinic effect of neostigmine on the heart is potent. Profound bradycardia after neostigmine has been reported in a patient taking propranolol. ${ }^{63}$ Atropine and neostigmine should not be given combined in a bolus to patients on propranolol. Atropine $0.6 \mathrm{mg}$ should be given first; then neostigmine is given in small increments, alternating with further increments of atropine when required. To avoid an excess of neostigmine, the use of the peripheral nerve stimulator is most helpful. Close observation of the heart rate and blood pressure during this period is mandatory.

\section{Postoperative Management}

Very little is written about the continuation of propranolol therapy in the postoperative period. Since catastrophe and death can strike as early as twenty-four hours after abrupt withdrawal, it is only logical that the surgical patient should be allowed to go back to his maintenance dose as early as possible. For patients who have to $a b$. stain from oral intake postoperatively, the intravenous route should be considered. A continuous infusion of propranolol in $S$ per cent dextrose in water at a rate of 10 per cent of the patient's usual daily oral dose over twenty-four hours should be started. ${ }^{64}$ This infusion rate can be further adjusted according to the haemodynamic response of the patient. As hepatic blood flow is reduced in the haemodynamically unstable patient, the hepatic extraction and elimination of propranolol is reduced due to a haemodynamic-drug interaction. ${ }^{41}$ The intravenous infusion of propranolol in the critically ill surgical patient should be observed closely in an intensive care area, as frequent adjustment of the rate may be necessary.

\section{The Management of Profound Bradycardia AND HYPOTENSION}

Most anaesthetized patients can tolerate a heart rate as low as $50 / \mathrm{min}$. They will not become hypotensive unless they are hypovolaemic. However, there is always the risk of profound bradycardia and hypotension in all patients under the combined effect of beta blockade and anaesthesia. The anaesthetist should be prepared for these complications. There are many pharmacologic agents that can counteract the nega- 
tive chronotropic and negative inotropic effects of beta-adrenergic blockade; but atropine and beta agonists are, by far, the most effective.

\section{Atropine}

Atropine, the drug of choice when bradycardia is present, should be given in $0.6 \mathrm{mg}$ increments to a total of two to three $\mathrm{mg}$ as necessary. It is a vagolytic agent which allows residual sympathetic stimulation of the heart to emerge.

\section{Beta-adrenergic Agents}

Propranolol is a competitive antagonist. Its action can be reversed by the use of a beta agonist. Isoproterenol, a pure agonist, is the agent of choice. It should be given as a continuous intravenous infusion: start with 2 to $5 \mu \mathrm{g} / \mathrm{min}$ and adjust the rate to obtain the desired effects. Extremely high doses may be needed.

Epinephrine is predominantly a beta agonist with some alpha effect on skin and visceral vascular beds. Due to this alpha effect, it may be more efficacious in maintaining blood pressure. The initial infusion rate is $5 \mu \mathrm{g} / \mathrm{min}$.

Dopamine, like norepinephrine and epinephrine, is an endogenous catecholamine. ${ }^{65}$ Its action on the heart is beta-adrenergic in nature. Unlike the other catecholamines, a therapeutic concentration of dopamine dilates the renal, mesenteric, coronary and cerebral microcirculations through dopaminergic receptors. At higher concentrations, the effect of dopamine on the peripheral circulation is uniformly vasoconstriction. It has a lesser effect on the heart rate than isoproterenol and epinephrine. The recommended initial rate of infusion is 2 to $5 \mu \mathrm{g} \cdot \mathrm{kg}^{-1} / \mathrm{min}$ which can be increased in steps up to $50 \mu \mathrm{g} \cdot \mathrm{kg}^{-1} / \mathrm{min}$ to obtain the desired circulatory response. When the dose is in excess of $50 \mu \mathrm{g} \cdot \mathrm{kg}^{-1} / \mathrm{min}$ its alpha effect on the peripheral circulation predominates.

Dobutamine, a synthetic agent, has pharmacological actions similar to those of dopamine. ${ }^{66}$ Its effect on the heart rate is even less than that of dopamine. Its intravenous infusion can start at 2.5 to $10 \mu \mathrm{g} \cdot \mathrm{kg}^{-1} / \mathrm{min}$.

\section{Alpha-adrenergic Agents}

Vasopressors with pure alpha effects (norepinephrine, methoxamine and phenylephrine) increase peripheral vascular resistance without any direct effect on the myocardium. If the beta-blocked and depressed heart is unable to cope with the increase in afterload, cardiac func- tion will deteriorate rapidly. These agents are not recommended.

\section{Xanthines}

Aminophylline blocks the enzymatic breakdown of cyclic AMP by phosphodiesterase. ${ }^{15}$ Since cyclic AMP mediated activation of kinase is an important step in the beta-adrenergic mechanism, aminophylline has beta-like activity. It works best when given in conjunction with a beta agonist. The recommended dose is 4 to $6 \mathrm{mg} \cdot \mathrm{kg}^{-1}$ given intravenously over 15 minutes.

\section{Cardiac Glycosides}

Digitalis inhibits the sodium-potassium pump of myocardial cell membrane and secondarily promotes the influx of calcium ions into myocardial cells ${ }^{67} \mathrm{As}$ a result, the increase in the sarcoplasmic pool of calcium ions increases the efficiency of excitation-contraction coupling and improves contractility. Except in the presence of bradycardia and $\mathrm{A}-\mathrm{V}$ block, rapid digitalization with intravenous digoxin is useful in patients not already digitalized.

\section{Calcium Salts}

The exact mechanism by which calcium salts improve myocardial contractility remains speculative. ${ }^{68}$ Calcium affects permeability of cell membrane to sodium and potassium. It has little effect on the resting membrane potential, but modifies induced action potential. It also plays a central role in excitation-contraction coupling. The action of calcium ions on the myocardium resembles that of digitalis. Since it is believed that digitalis exerts its effect indirectly through the influx of calcium ions into myocardial cells, calcium salts may exert their effect by increasing the sarcoplasmic pool of calcium ions. It antagonizes the negative inotropic effect of halothane in man. ${ }^{69}$ It is also effective, though less potent, in dogs anaesthetized with halothane and pretreated with beta antagonists. ${ }^{70}$ One-half to one gram of calcium chloride or calcium gluconate can be administered slowly intravenously under electrocardiographic monitoring.

\section{Glucagon}

Glucagon can activate adenyl cyclase by interacting with specific and non-beta-adrenergic receptors: ${ }^{11}$ thus it bypasses beta blockade. ${ }^{71}$ It has both chronotropic and inotropic effects in man even in the presence of beta-adrenergic blockade, catecholamine depletion and full dig- 
italization. ${ }^{72}$ Its action is not always predictable and it has been reported to be ineffective, ${ }^{2}$ It should be tried in combination with other agents. Five to ten milligrams should be given intravenously followed by an infusion of $1 \mathrm{mg} / \mathrm{min} .{ }^{6}$ Side effects of glucagon administration include nausea and vomiting, hypoglycaemia (a result of depletion of glycogen store after prolonged administration) and a minor fall in serum potassium. ${ }^{73}$

Besides pharmacological measures, the depth of anaesthesia should be reduced when possible to minimize central nervous system and myocardial depression. Surgical manipulation of viscera should be stopped to avoid evoking unwanted vagal reflexes and fluid administration should be increased to meet blood loss and third space loss when indicated. It should be remembered that in the presence of beta blockade, tachycardia may not occur even when hypovolaemia is severe. On the other hand, the beta-blocked heart can be over-loaded rapidly. If more than a modest amount of intravenous fluid is used, central venous pressure or pulmonary capillary wedge pressure should be monitored.

\section{REFERENCES}

1. Black, J.W., Crowther, A.F., Shanks, R.G. SMITH, L.H. \& DoRNhorst, A.C. A new adrenergic beta-receptor antagonist. Lancet $l: 1080(1964)$.

2. Viljoen, J.F., Estafanous, F.G. \& Kellner, G.A. Propranolol and cardiac surgery. J. Thorac. Cardiovasc. Surg. 64: 826 (1972).

3. FABIAN, L.W., Ayscue, Q.A., Brown, B.R., JR., Frederickson, E.L., MoRrow, D.H. \& Shimosato, S. The experts opine. Sury. Anesthesiology 16: 484 (1972).

4. Caralps, J.M., Mulet, J., Wienke, H.R., MORAN, J.M. \& Pifarre, R. Results of coronary artery surgery in patients receiving propranolol. $\mathbf{J}$. Thorac. Cardiovase. Surg. 67: 526(1974).

5. Kopriva, C.J., Brown, A.C.D. \& Pappas G. Hemodynamics during general anesthesia in patients receiving propranolol. Anesthesiology 48: 28 (1978).

6. Kaplan, J.A. \& Dunbar, R.W. Propranolol and surgical anesthesia. Anesth. Analg. (Cleve.) 55:1 (1976).

7. Haidinyak, J.G. \& Didier, E.P. Case history number 95: anesthetics and propranolol. Anesth. Analg. (Cleve.) 56: 283 (1977).

8. Greenblatt, D.J. \& Koch-Weser, J. Adverse reactions to propranolol in hospitalized medical patients: a report from the Boston Collaborative Drug Surveillance Program. Am. Heart J. 86: 478 (1973).

9. Davidson, C., Thadani, U., Singleton, W. \& TAYLOR, S.H. Comparison of antihypertensive activity of beta-blocking drugs during chronic treatment. Br. Med. J. 2: 7 (1976).
10. Thadani, U., Davidson, C., Singleton, W. \& TAYLOR, S.H. Comparison of the immediate effects of five $\beta$-adreno-receptor-blocking drugs with different ancillary properties in angina pectoris. $N$. Engl. J. Med. 300: 750 (1979).

11. Sutherland, E.W., Robison, G.A.\& Butcher, R.W. Some aspects of the biological role of adenosine 3',5'-monophosphate (Cyclic AMP). Circulation 37: 279 (1968).

12. Butcher, R.W. Role of cyclic AMP in hormone actions. N. Engl. J. Med. 279: 1378 (1968).

13. Wiklund, R.A. Cyclic nucleotides. Anesthesiology $41: 490$ (1974).

14. Epstein, S.E. \& Braunwald, E. Beta-adrenergic receptor blocking drugs - mechanisms of action and clinical applications. N. Engl. J. Med. 275: 1106 (1966)

15. RALL, T.W. \& WEST, T.C. The potentiation of cardiac inotropic responses to norepinephrine by theophylline. J. Pharmacol. Exp. Ther. 139: 269 (1963).

16. Epstein, S.E. \& Braunwald, E. Beta-adrenergic receptor blocking drugs - mechanisms of action and clinical applications (concluded). N. Engl. J. Med. 275: 1175 (1966)

17. Gibson, D. \& Sowton, E. The use of betaadrenergic receptor blocking drugs in dysrhythmias. Prog. Cardiovasc. Dis. 12: 16 (1969).

18. Bühler, F.R., Laragh, J.H., Vaughan, E.D., Jr., Brunner, H.R., Gavras, H. \& Baer, L. Antihypertensive action of propranolol - specific antirenin responses in high and normal renin forms of essential, renal, renovascular and malignant hypertension. Am. J. Cardiol. 32: 511 (1973).

19. Hollifield, J.W., Sherman, K., Zwage, R.V \& Shand, D.G. Proposed mechanisms of propranolol's antihypertensive effect in essential hypertension. N. Engl. J. Med. 295: 68 (1976).

20. Zacest, R., Gilmore, E. \& Koch-Weser, J. Treatment of essential hypertension with combined vasodilation and beta-adrenergic blockade. N. Engl. J. Med. 286: 617 (1972).

21. Frohlich, E.D., Tarazi, R.C., Dustan, H.P. \& PAGE, 1.H. The paradox of beta-adrenergic blockade in hypertension. Circulation 37: 417 (1968).

22. LydTin, H., Kusus, T., Daniel, W., Schierl, W., Ackenheil, M., Kempter, H., Lohmöller, G., NikLAS, M. \& WaLter, I. Propranolol therapy in essential hypertension. Am. Heart J. 83: 589 (1972).

23. Stern, S., Hoffman, M. \& Braun, K. Cardiovascular responses to carotid and vertebral artery infusions of propranolol. Cardiovasc. Res. 5: 425 (1971).

24. Myers, M.G., Lewis, P.J., Reid, J.L. \& DolLERY, C.T. Brain concentration of propranolol in relation to hypotensive effect in the rabbit with observations on brain propranolol levels in man. J. Pharmacol. Exp. Ther. 192: 327 (1975).

25. Paterson, J.W., Conolly, M.E., Dollery, C.T., Hayes, A. \& Cooper, R.G. The pharmacodynamics and metabolism of propranolol in man. Eur. J. Clin. Pharmacol. 2: 127 (1970).

26. Bond, P.A. Metabolism of propranolol ('Inderal'), a potent, specific $\beta$-adrenergic receptor blocking agent. Nature 213: 721 (1967). 
27. Shand, D.G. \& Rangno, R.E. The disposition of propranolol. I. Elimination during oral absorption in man. Pharmacology 7: 159 (1972).

28. Evans, G.H., Nies, A.S. \& Shand, D.G. The disposition of propranolol. III. Decreased half-life and volume of distribution as a result of plasma binding in man, monkey, dog and rat. J. Pharmacol. Exp. Ther. 186: 114 (1973).

29. Fitzgerald, J.D. \& O'Donnell, S.R. Pharmacology of 4-hydroxypropranolol, a metabolite of propranolol. Br. J. Pharmacol. 43: 222 (1971).

30. SHAND, D.G. Individualization of propranolol therapy. Med. Clin. North Am. 58: 1063 (1974).

31. NiEs, A.S. \& SHAND, D.G. Clinical pharmacology of propranolol. Circulation 52: 6(1975).

32. Shand, D.G., Nuckolls, E.M. \& OAtes, J.A. Plasma propranolol levels in adults - with observations in four children. Clin. Pharmacol. Ther. 11 : 112 (1970).

33. George, C.F. \& Dollery, C.T. Plasma concentrations and pharmacological effect of $\beta$-receptor blocking drugs. Pharmacology and the Future of Man. Proc. Sth Int. Congr. Pharmacology, San Francisco 1972. 3: 86 (Karger, Basel 1973).

34. Zacharias, F.J., Cowen, K.J., Prestt, J., Vickers, J. \& WALL, B.G. Propranolol in hypertension: a study of long-term therapy, 1964-1970. Am. Heart J. 83: 755 (1972).

35. Shand, D.G. Propranolol. N. Engl. J. Med. 293: $280(1975)$.

36. Evans, G.H. \& Shand, D.G. Disposition of propranolol. VI. Independent variation in steady-state circulating drug concentrations and half-life as a result of plasma drug binding in man. Clin. Pharmacol. Ther. 14: 494 (1973).

37. Coltart, D.J., Cayen, M.N., Stinson, E.B., DAVIES, R.O. \& HARRISON, D.C. Determination of the safe period for withdrawal of propranolol therapy. Circulation 47-48, Supp. IV: IV-7 (1973).

38. Faulkner, S.L., Hopkins, J.T., Boerth, R.C., Young, J.L., JR., JelleTt, L.B., Nies, A.S., Bender, H.W. \& Shand, D.G. Time required for complete recovery from chronic propranolol therapy. N. Engl. J. Med. 289: 607 (1973).

39. Romagnoli, A. \& KeAts, A.S. Plasma and atrial propranolol after preoperative withdrawal. Circulation 52: 1123 (1975).

40. Nies, A.S., Evans, G.H. \& Shand, D.G. Regional hemodynamic effects of beta-adrenergic blockade with propranolol in the unanesthetized primate. Am. Heart J. 85: 97 (1973).

41. Nies, A.S., Evans, G.H. \& Shand, D.G. The hemodynamic effects of beta adrenergic blockade on the flow-dependent hepatic clearance of propranolol. J. Pharmacol. Exp. Ther. 184: 716 (1973).

42. Shand, D.G., Evans, G.H. \& Nies, A.S. The almost complete hepatic extraction of propranolol during intravenous administration in the dog. Life Sci. 10: 1417 (1971).

43. Alderman, E.L., Coltart, D.J., Wettach, G.E. \& Harrison, D.C. Coronary artery syndromes after sudden propranolol withdrawal. Ann. Intern. Med. 81: 625 (1974).

44. Mizgala, H.F. \& Counsell, J. Acute coronary syndromes following abrupt cessation of oral propranolol therapy. Can. Med. Assoc. J. 114: 1123 (1976).
45. Shand, D.G. \& Wood, A.J.J. Propranolol withdrawal syndrome - why? Circulation 58: 202 (1978).

46. Nattel, S., Rangno, R.E. \& Van Loon, G. Mechanism of propranolol withdrawal phenomena. Circulation 59: 1158 (1979).

47. Williams, C.H., BeutsCh, S., Linde, H.W., Bullough, J.W. \& DRIPPS, R.D. Effects of intravenously administered succinyldicholine on cardiac rate, rhythm, and arterial blood pressure in anesthetized man. Anesthesiology 22: 947 (1961).

48. Stoelting, R.K. \& Peterson, C. Adverse effects of increased succinylcholine dose following $d$ tubocurarine pretreatment. Anesth. Analg. (Cleve.) 54: 282 (1975).

49. Stoelting, R.K. \& Peterson, C. Heart-rate slowing and junctional rhythm following intravenous succinylcholine with and without intramuscular atropine preanesthetic medication. Anesth. Analg. (Cleve.) 54: 705 (1975).

50. Chung, D.C. Upublished observation.

51. Chatas, G.J., Gottlieb, J.D. \& Sweet, R.B. Cardiovascular effects of d-tubocurarine during Fluothane anesthesia. Anesth. Analg. (Cleve.) 42: 65 (1963)

52. Munger, W.L., Miller, R.D. \& Stevens, W.C. The dependence of d-tubocurarine-induced hypotension on alveolar concentration of halothane, dose of d-tubocurarine, and nitrous oxide. Anesthesiology 40: 442 (1974).

53. McCullough, L.S., Stone, W.A., Delaunois, A.L., Reier, C.E. \& Hamelberc, W. The effect of dimethyl tubocurarine iodide on cardiovascular parameters, postganglionic sympathetic activity, and histamine release. Anesth. Analg. (Cleve.) 51: 554 (1972).

54. Zaidan, J., Philbin, D.M., Antonio, R. \& SAVARESE, J. Hemodynamic effects of metocurine in patients with coronary artery disease receiving propranolol. Anesth. Analg. (Cleve.) 56: 255 (1977).

55. Kelman, G.R. \& Kennedy, B.R. Cardiovascular effects of pancuronium in man. $\mathrm{Br}$. J. Anaesth. 43: 335 (1971).

56. Hsu, H.O., Hickey, R.F. \& Forees, A.R. Morphine decreases peripheral vascular resistance and increases capacitance in man. Anesthesiology 50: 98 (1979).

57. Slogofy, S., Keats, A.S., Hibrs, C.W., EdMONDS, C.H. \& BRAGG, D.A. Failure of general anesthesia to potentiate propranolol activity. Anesthesiology 47: 504 (1977).

58. Calverley, R.K., Smith, N.T., Prys-Roberts, C., Eger, E.I., II. \& Jones, C. W. Cardiovascular effects of enflurane anesthesia during controlled ventilation in man. Anesth. Analg. (Cleve.) 57: 619 (1978).

59. Roberts, J.G., FoËx, P., Clarke, T.N.S. \& BeNNeTt, M.J. Haemodynamic interactions of high-dose propranolol pretreatment and anesthesia in the dog. I. Halothane dose-response studies. $\mathrm{Br}$. J. Anaesth. 48: 315 (1976).

60. Horan, B.F., Prys-Roberts, C., Hamilton, W.K. \& RobeRTS, J.G. Haemodynamic responses to enflurane anaesthesia and hypovolaemia in the $\mathrm{dog}$, and their modification by propranolol. $\mathrm{Br}$. J. Anaesth. 49: 1189 (1977). 
61. Philbin, D.M. \& Lowenstein, E. Lack of betaadrenergic activity of isoflurane in the dog: a comparison of circulatory effects of halothane and isoflurane after propranolol administration. $\mathrm{Br}$. J. Anaesth. 48: 1165 (1976).

62. Saner, C.A., Fö̈x, P., Roberts, J.G. \& BenNETT, M.J. Methoxyflurane and practolol: a dangerous combination? Br. J. Anaesth. 47: 1025 (1975).

63. Sprague, D.H. Severe bradycardia after neostigmine in a patient taking propranolol to control paroxysmal atrial tachycardia. Anesthesiology 42: 208 (1975)

64. Rotem, C.E. Propranolol therapy in the perioperative period. Can. Med. Assoc. J. 114: 188 (1976).

65. Goldberg, L.I. Dopamine - clinical uses of an endogenous catecholamine. N. Engl. J. Med. 29l: 707 (1974).

66. Sonnenblick, E.H., Frishman, W.H. \& LeJemTEL, T.H. Dobutamine: a new synthetic cardioactive sympathetic amine. N. Engl. J. Med. 300: 17 (1979).

67. MoE, G.K. \& Farah, A.E. Digitalis and allied cardiac glycosides. In: (Goodman, L.S. \& Gilman, A., eds.) The pharmacological Basis of Therapeutics, 5th ed. New York: MacMillan (1975).
68. PeACH, M.J. Cations: calcium, magnesium, barium, lithium, and ammonium. In: (Goodman, L.S. \& Gilman, A., eds.) The Pharmacological Basis of Therapeutics, 5th ed. New York: MacMillan (1975).

69. Denlinger, J.K., Kaplan, J.A., Lecky, J.H. \& Wollman, H. Cardiovascular responses to calcium administered intravenously to man during halothane anesthesia. Anesthesiology 42: 390 (1975).

70. Prys-Roberts, C., Roberts, J.G., FoËx, P. Clarke, T.N.S., BenNeTt, M.J. \& Ryder, W.A. Interaction of anesthesia, beta-receptor blockade, and blood loss in dogs with induced myocardial infarction. Anesthesiology 45: 326 (1976).

71. Glick, G., Parmley, W.W., Wechsler, A.S. \& SONNENBLICK, E.H. Glucagon: its enhancement of cardiac performance in the cat and dog and persistence of its inotropic action despite beta-receptor blockade with propranolol. Circ. Res. 22: 789 (1968).

72. Parmley, W.W., Glick, G. \& Sonnenblick, E.H., Cardiovascular effects of glucagon in man. N. Engl. J. Med. 279: 12 (1968).

73. ParmLEY, W.W. The role of glucagon in cardiac therapy. N. Engl. J. Med. 285: 801 (1971).

RÉSUMÉ

Plusieurs antagonistes bêta-adrénergiques sont disponibles pour usage clinique. L'action de tous ces agents chez des malades à cardiopathie ischémique et chez les hypertendus est semblable à ceux du prototype: le propranolol.

Au moins trois pour cent des malades sous propranolol sont susceptibles de présenter des complications cardiaques d'importance suffisante pour menacer leur vie. L'addition des effets des agents anesthésiques à la dépression circulatoire produite par les bêta-bloquants peut créer des problèmes importants chez les malades chirurgicaux. Aussi faut-il évaluer et prẻparer soigneusement les malades chirurgicaux qui reçoivent une telle médication.

Il existe des différences individuelles dans la sensibilité des récepteurs adrénergiques ainsi que dans les effets des bêta-bloquants. De plus, on ne peut assumer que les malades se conforment de façon stricte aux doses médicamenteuses prescrites. C'est pourquoi on ne peut se fier à la dose journalière prescrite pour évaluer le degrée de blocage bêta. Un examen cardiovasculaire détaillé est donc indiqué. Il n'est pas nécessaire de suspendre ou de réduire les doses de propranolol avant la chirurgie chez le malade bloqué de façon optimale; on devra cependant prendre des mesures correctrices chez les malades recevant des doses toxiques.

Le choix des agents anesthésiques doit être fait en tenant compte des interactions entre ces agents et les bêta-bloquants. Les effets additifs sur la circulation de l'association des bêtabloquants et de l'halothane ou des bêta-bloquants avec la morphine sont bien connus. Ceux de l'enflurane combinés aux bêta-bloquants sont moins prédictibles. L'association propranolol-isoflurane a des effets négligeables, mais celle du méthoxyflurane avec le practolol semble inacceptable. Il y a des inconvénients pratiques et théoriques à l'emploi de la succinylcholine (à cause de ses effets muscariniques) et à l'usage de la d-tubocurarine (bloc ganglionnaire sympathique). La diméthyl-tubocurarine et le pancuronium représentent de bons choix. La néostigmine, si on doit l'employer, devrait être administrée en doses fractionnées et seulement après avoir donné la pleine dose d'atropine.

Un infarctus du myocarde peut survenir 24 heures après sevrage aigu des bêta-bloquants. Aussi, la dose de maintien devrait-elle être reprise aussitôt que possible après l'intervention. L'administration par perfusion intraveineuse est recommandée si la voie orale n'est pas possible précocément. En cas de bradycardie et d'hypotension grave, l'usage des agonistes bêta peut permettre de renverser le bloc compétitif produit par les bêta-bloquants. L'atropine, l'aminophylline, les glucosides cardiaques, le sels de calcium et le glucagon peuvent également être indiqués dans ces cas. 